\title{
Mühendislik öğrencilerinin öğrenim yeterlilikleri ve mesleki yetkinlikleri: inşaat mühendisliği öğrenci perspektifi
}

\author{
Savaş Bayram \\ Erciyes Üniversitesi, Kayseri, Türkiye, sbayram@erciyes.edu.tr \\ Gözde Tantekin Çelik \\ Çukurova Üniversitesi, Adana, Türkiye, gtantekin@yahoo.com \\ Emel Laptalı Oral \\ Çukurova Üniversitesi, Adana, Türkiye, eoral@cu.edu.tr
}

ÖZET Her yıl çok sayıda öğrenci inşaat mühendisliği bölümlerine yerleşmektedir. Öğrencilerin, gelecekte nitelikli birer meslek insanı olmaları, bu tercihin bilinçli yapılmasına bağlıdır. Bununla beraber nitelikli bireylerin yetişmesinde eğitimin kalitesi önem kazanmaktadır. Çünkü üniversite eğitimi sırasında kazanılan genel ve mesleki yetkinlikler, bireyin iş hayatının temelini oluşturmaktadır. Bu çalışma kapsamında öğrencilerin tercih kararlarının sorgulanması ve kendilerini mesleki ve genel yetkinlikler açısından değerlendirmeleri amacıyla; Çukurova, Erciyes ve Gazi Üniversitesi'ne bağlı inşaat mühendisliği bölümlerinin son sınıf öğrencilerine dört bölümden oluşan bir anket çalışması uygulanmıştır. Anket sonuçlarına göre öğrencilerin üniversite tercihlerinde üniversitenin kalitesi, bölüm tercihlerinde ise mesleğe olan ilgileri en önemli etkendir. Genel yetkinlikleri konusunda öğrenciler 'başkalarıyla iyi ilişkiler kurabilme' konusunda başarılı olduklarını düşünmektedirler. Mesleki yetkinlik konusunda ise; betonarme yapılar, yapı işletmesi/inşaat yönetimi, su yapıları alanlarında yeterli, kıyı-liman yapıları alanında yetersiz olduklarını ifade etmişlerdir. Çalışmanın Türkiye'deki inşaat mühendisliği eğitimi alanını bu yönden inceleyen ilk çalışmalardan birisi olması nedeni ile ileriki çalışmalarda yol gösterici olacağ düşünülmektedir.

Anahtar
Sözcükler Mühendislik Eğitimi, İnşaat Mühendisliği, Bilinçli Tercih, Yetkinlik

\section{Educational qualification and vocational competence of engineering students: civil engineering student perspective}

ABSTRACT Every year, many students choose to have education in civil engineering. Choosing their profession conciously is very important for their future success. However the quality of education is another factor that affects qualifications of individuals. Acquiring general and vocational competencies during the university education are the foundation of business life. The purpose of this study is; to present the criterions that affect the university/department choices of students and their vocational and general competencies. For this purpose; a survey was applied to $4^{\text {th }}$ grade civil engineering department students of Cukurova, Erciyes and Gazi universities. The results show that students' university preferences are affected by quality of the university. Meanwhile, their department preferences are affected by their interest in the profession. Students consider themselves to be good at 'their relationships with others and feel competent in; concrete structures, construction management, hydraulic structures. However, they do not feel qualified in coastal engineering. Current research, being one of the earliest in Turkey, makes its results valuable for future researchers. 


\section{EXTENDED SUMMARY}

Number of civil engineering departments in Turkish universities is increasing year by year which are far ahead the needs of the country. While a total of 47 universities ( 39 state and 8 private) had civil engineering departments as recently as year 2009, a total of 103 universities (67 state and 36 private) have civil engineering departments today. The increase in the number of civil engineering students between 2009 and 2013 is $97 \%$. So, many students who pass the university entrance exams choose to have education in these civil engineering departments. While some of these students make their choices consciously and willingly; some make their choices under the affect of many factors like the pressure from the family members or financial state of the family and so on. However, a successful career in the future depends on the student's willingness and consciousness in learning his/her profession together with the quality of the education given to the student. The purpose of this study is thus; to present both the criterions that affect the university/department choices of civil engineering students and the quality of education they have by focusing on the students' perspectives regarding their vocational and general competencies. A similar study by Oguz et al. (2009) was used as an important reference point during the questionnaire preparation and analysis stages of the current study. Current questionnaire survey consisted of four main sections and a total of 181 fourth grade civil engineering students from Cukurova University, Erciyes University and Gazi University responded to the survey. In the first section; general information about students (university, socio-economic status, etc.) were asked. In the second section; factors influencing the choice of university besides the department; in the third section; ideas about the department and expectations from the future; in the fourth section;questions related with general and vocational competences; were asked. The results of the survey were statistically interpreted. The statistical analyses were accomplished by using "Microsoft Office Excel 2003 for Windows" and "Statistical Package for Social Sciences (SPSS) 17.0 for Windows" software programs.

The questionnaire results show that; quality of the university and desire to study in a big city were the most important factors affecting the students' university choice, where the interest in the profession was emerged as the most important factor for the students' department choice. Also the oppressive attitude of family members for the department choice was seen to be ineffective. For the students' expectancy from future; moral values were more important than material values. For the general competencies, students thought that they were successful in establishing good relations with others. It was concluded that homeworks and class presentations should focus on developing oral-written communication skills and self-confidence of the students. Related with the vocational competence, it was clear that the students were qualified in the fields of; reinforced concrete structures, construction management, waterstructures, technical drawings and building materials while they felt inadequate in the area of the coastal-harbor structures. Besides, students thought that they were weak on the use of the structural analysis software packages. Finally, it was determined that while the students had sufficient English level, they were quite inadequate in other foreign languages. As an addition, correlations between different sections were analyzed. The highest correlation value was obtained between the answers given to the second section (factors influencing the choice of university besides the department) and the third section (ideas about the department and expectations from the future). This result demonstrated that conscious and willing choice of study subjects and departments by the students increased satisfaction of the students.

Current research results are valuable for future researches, as current research being one of the earliest studies related to civil engineering education in Turkey. Future research should not only focus on student perspectives but also focus on the perspectives of other stakeholders of the civil engineering education and the results should be evaluated as a whole. 


\section{GİRIŞ}

Türkiye'de 1980'li yıllardan sonra üniversitelerde inşaat mühendisliği eğitimi veren bölüm sayısı ülke ihtiyacı ve bilimsel beklentilerin ötesinde bir sayısal artış göstermiştir. Ancak bu bölümlerde, özellikle lisans düzeyindeki eğitimin, global düzeyde bir gelişme gösteremediği ve nitelik gelişiminin tamamlanamadı ̆̆ı görülmektedir (Birinci ve Koç, 2007). EK 1 olarak çalışmanın sonunda yer alan Tablo 1 (a ve b)'de, Ögrenci Seçme ve Yerleştirme Sistemi (ÖSYS) ile inşaat mühendisliği bölümlerine öğrenci kabul eden üniversitelerin 2009-2013 yılları arasına ait beş yılı kapsayan öğrenci kontenjanları ve öğretim üyesi/öğretim görevlisi sayıları yer almaktadır.

Tablo 1'den görüldüğü üzere, günümüzde devlet üniversitelerinin inşaat mühendisliği bölümleri 8292 öğrenci kontenjanına, 1028 öğretim üyesi ve öğretim görevlisine sahipken, vakıf üniversitelerinin inşaat mühendisliği bölümleri 2632 öğrenci kontenjanına, 93 öğretim üyesi ve öğretim görevlisine sahiptir. Bu durumda, öğretim üyesi ve öğretim görevlisi başına düşen öğrenci kontenjanı devlet üniversitelerinde 8.07, vakıf üniversitelerinde 28.30 ve genel dağılımda ise 9.74 'tür. Ortalama bir hesapla; dört yıllık üniversite öğrenimi sürecinde, öğretim üyesi ve öğretim görevlisi başına düşen öğrenci sayıs1; 9.74 x 4 = 38.96 olarak elde edilir. Ülkemizdeki üniversitelere genel olarak bakıldığında; 1984-2011 döneminde öğretim üyesi başına düşen öğrenci sayısının 41-49 aralığında olduğu bilinmektedir (Balas, 2009; Günay ve Günay, 2011). 2011 yılında öğretim üyesi başına düşen öğrenci sayısı ise 45.98 olarak ifade edilmiştir (Günay ve Günay, 2011). Bahsedilen genel çerçevede, öğretim üyesi ve öğretim görevlisi başına düşen 38.96 öğrenci, genel anlamda ifade edilen 45.98 öğrenciye göre daha az olsa da, 2008 OECD ülkeleri öğretim elemanı başına düşen öğrenci sayısı ortalamasına (15.8) göre oldukça yükssektir (OECD 2010; OECD 2013). Bunun yanısıra, 2009 yılında 39 devlet ve 8 vakıf üniversitesi olmak üzere toplam 47 üniversitede inşaat mühendisliği eğitimi verilmekte iken, 2013 yılı itibariyle 67 devlet ve 36 vakıf üniversitesi olmak üzere toplam 103 üniversitede inşaat mühendisliği eğitimi verilmektedir. Rakamların daha somut değerlendirilebilmesi adına, inşaat mühendisliği bölümlerine kabul edilen öğrenci sayıları, yıl bazında Şekil 1'de gösterilmektedir.

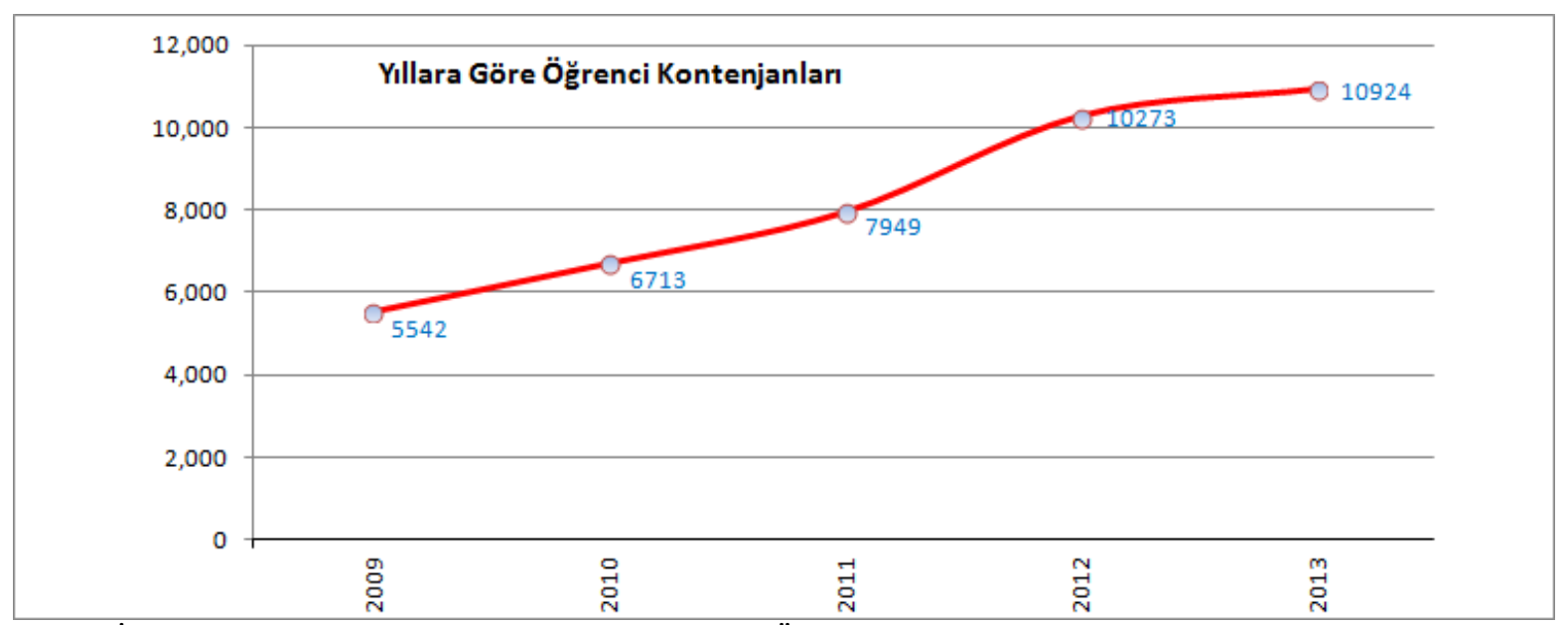

Şekil 1. İnşaat Mühendisliği Bölümlerine Kabul Edilen Öğrenci Sayılarının Yıllara Göre Dağılımı

Tablo 1 (a ve b)'den ve Şekil 1'den de görüldüğü üzere, mevcut inşaat mühendisliği bölümlerinin kontenjanlarının artması ve yeni inşaat mühendisliği bölümlerinin açılmasıyla birlikte, inşaat mühendisliği bölümlerinin yıllara göre öğrenci kontenjanlarında keskin yükselişler göze çarpmaktadır. 2009 yılı itibarı ile üniversitelerin inşaat mühendisliği bölümlerinde toplam 735 öğretim üyesi bulunmaktadır (Balas, 2009). Günümüzde ise üniversitelerin inşaat mühendisliği bölümlerinde toplam 1058 öğretim üyesi bulunmaktadır. Bu rakama dayanılarak; 2009-2013 yılları arasındaki beş yıllık süreçte, öğretim üyesi sayıları \%44 oranında artarken, inşaat mühendisliği bölümlerinin öğrenci kontenjanlarının \%97 oranında arttığı söylenebilir.

Yukarıda özetlendiği üzere, ülkemizde inşaat mühendisliği lisans eğitiminin, sürekli artan kontenjanlara paralel olarak, genel ve mesleki yetkinlikleri yeterli mezunlar verebilmesinin çok mümkün olmadığı görülmektedir. Söz konusu durumun somut olarak değerlendirilebilmesi açısından eğitim sürecinin tüm paydaşlarının (öğrenciler, eğitimciler, işverenler) konuya bakış açlarının/tecrübelerinin bilimsel 
yöntemler kullanılarak belirlenmesi önemli olacaktır. Bu çalışmanın amacı da Gross ve Godwin (2005), Oğuz vd. (2009) ve Maric (2013) gibi yazarların da belirttiği gibi; konuyla ilgili en önemli paydaş olan öğrencilere bir anket düzenleyerek öz eleştiri yapmalarını sağlamak ve toplanan veriler 1şığında öğrencilerin öğrenim yeterlilikleri ve mesleki yetkinlikleri konusunda değerlendirmelerde bulunmak, olarak özetlenebilir.

\section{Önceki Çalışmalar}

Literatürde mühendislik eğitimi ile ilgili farklı çalışmalara rastlanmıştır. Papert (1980), Warszawski (1984), Riggs (1988), Gençoğlu ve Cebeci (1999), Liu ve Fang (2002), Çiçek vd. (2004), Yenigün ve Gürel (2004), Baran ve Kahraman (2004), Christodoulou (2004), Gençoğlu ve Gençoğlu (2005a), Gençoğlu ve Gençoğlu (2005b), Leung vd. (2006), Aytekin (2006), Uğur (2007), Sorguç (2007), Birinci ve Koç (2007), Birinci (2009), Engin, Atalay ve Okay (2009), Çeçen vd. (2009), Ertaş, Öztaş ve Tekinkuş (2009), Balas (2009), Oğuz vd. (2009), Mistıkoğlu (2010), Bayram vd. (2011) ve Mistıkoğlu (2012)'nun çalışmaları bu konuda yapılmış belli başlı örneklerdir. Bu çalışmalarda mühendislik eğitiminin farklı boyutlarlarda ele alınmış olmasından dolayı aşağıda yalnızca inşaat mühendisliği eğitimi ile ilgili temel çalışmalar sıralanmıştır.

Liu ve Fang (2002), inşaat mühendisliği eğitiminin mevcut sorunlarını tartışmaya açmışlardır. Çin Halk Cumhuriyeti'ndeki yetkin inşaat mühendislerinin taleplerini de dikkate alarak, inşaat mühendisliği eğitiminin temel hedeflerinin; bütünleşik bilgi yapısı, çok katmanlı inovasyon, adaptasyon, işbirliği, iletişim ve organizasyon olması gerektiğini ifade etmişlerdir. Sonuç olarak; öğrenci merkezli eğitim, eğitim organizasyonu dinamikleri ve açık eğitim kavramlarına ağırık verilmesi önerilmiştir.

Yenigün ve Gürel (2004), Türkiye'deki inşaat mühendisliği eğitiminin mevcut durumunu dikkate alarak, "Daha iyi bir mühendislik eğitimi nasıl olur?" sorusuna bilimsel ve sistematik bir yaklaşımla katkıda bulunmayı amaçlamışlardır. Çalışma kapsamında; eğitimin sorgulayıcı, araştırıcı ve irdeleyici mantıkla yürütülmesi gerektiği, temel derslerin inşaat mühendisliği bölümlerindeki öğretim elemanları tarafından verilmesi gerektiği, öğrenci sayısının belirlenmesinde minimum altyapının sağlanmasına özen gösterilmesi, paket programlar için özel sektöre dayalı kurslar programlanması, sağlıklı bir branşlaşma icin anket, gözlem ve değerlendirme çalışmalarının sonuçlarının değerlendirilerek uygun bir branşlaşma oluşturulması gibi öneriler sunulmuştur.

Leung vd. (2006), Hong Kong ve Çin'in genelindeki inşaat mühendisliği öğrencileri ile yaptıkları çalışmada Hong Kong'da eğitim alan öğrencilerin Çin'deki diğer öğrencilerden farklı olduklarını, daha yüzeysel bilgilerle çabuk başarıya ulaşma eğiliminde olduklarını belirlemişlerdir. Yazarlar öğrencilerin kolaycı yaklaşımlarını değiştirmek için üniversitelerin farklı teknikler ve yaklaşımlar kullanması gerektiğini öne sürmüşlerdir.

Uğur (2007), Türkiye'de inşaat mühendisliğinin, eğitim, uygulama, branşlaşma ve yetkinliği konularında genel bir panoramasının çıkarılması amacı ile inşaat mühendislerine anket çalışması uygulamıştır. Mühendislik eğitiminde kütüphane, laboratuvar, internet erişimi gibi altyapı donanımlarının yaygınlaştırılmasının yanı sıra uygulama, staj ve saha incelemelerinin daha öne çıkarılması gerekliliği, sağlıklı bir branşlaşma ve spesifik eğitimlerin verilmesi zorunluluğu ile şeffaflaşmanın her alanda olumlu katkıları olacağı sonuçlarına varılmıştır.

Birinci ve Koç (2007), inşaat mühendisliği eğitiminin tarihsel gelişimini inceleyerek, inşaat mühendisliğinin genel yapısı ve bu yapı içinde gelişme ve ilerlemeye engel olduğu düşünülen noktaları tespit etmişlerdir. Türkiye'de inşaat mühendisliği eğitiminin gelişmesi için, gelişmiş ülkelerde kullanılan modellerin kullanılabilir ve uygulanabilir yönlerinin temel alınması, üniversite öncesi eğitim sisteminin de dikkate alınarak düzenlemeler yapılması gerektiği sonucuna varılmıştır.

Birinci (2009), Türkiye'deki inşaat mühendisliği eğitiminin, fiziki koşullar ve öğretim elemanları, laboratuvar ve staj, öğrenci durumu ve öğrenim süresi, derslerin dağılım ve içerikleri ile eksikliklerin tespiti konularını kapsayan bir genel durum değerlendirmesi yapmıştır. Bunun yanı sıra inşaat mühendisliği bölümlerinin sorunları, eğitimde gelişmiş ülkelere göre eksik veya yetersiz olan dersler ile mezuniyet sonrası istihdam ve mevzuatın istihdama olumsuz etkileri ile ilgili incelemeler de yapılmıştır. Engin, Atalay ve Okay (2009), Kocaeli Üniversitesi Mühendislik Fakültesi İnşaat Mühendisliği bölümündeki üçüncü ve dördüncü sınıf öğrencilerine uyguladıkları anket çalışması ile öğrencilerin aldıkları eğitime bakış açılarını ele almışlardır. Çalışmada, modern teknolojilere uygun olarak nitelikli ve güvenli yapı üretebilecek seviyede eğitim almış inşaat mühendisleri yetiştirilmesi amacı ile yüksek öğrenim planlarının hazırlanması ve uygulanması gerektiği sonucuna ulaşılmıştır. 
Oğuz vd. (2009), İnşaat Mühendisleri Odası (İMO) tarafından üçüncü ve dördüncü sınıfta öğrenim gören 3284 öğrenciye yapılan anket çalışmasının sonuçlarını değerlendirerek sorunlara çözüm önerileri sunmuşlardır. Elde edilen bulgular; öğrenci ailelerinin \%55'inin aylık gelirinin 1500 TL'nin altında olduğunu, öğrenci ailelerinin \%37.9'unun İç Anadolu Bölgesi'nde yaşadığını, öğrencilerin \%57'sinin inşaat mühendisliği bölümünü ilk üç tercihi arasına yazdığını, öğrencilerin \%46'sının bölümü yeteneklerine uygun bulduğunu, \%86's1 eğitiminden memnun olduğunu, göstermiştir. Sonuç olarak; inşaat mühendisliği eğitiminde sistemin çözülmesi gereken önemli sıkıntılarının bulunduğu ifade edilmiştir.

Bayram vd. (2011); Çukurova Üniversitesi, Erciyes Üniversitesi ve Gazi Üniversitesi İnşaat Mühendisliği Bölümlerinde eğitim görmekte olan dördüncü sınıf öğrencilerine uyguladıkları anket çalışması ile öğrencilerin inşaat mühendisliği eğitimine, öğretim elemanlarına ve sorumlu oldukları derslerin uygulanış biçimlerine bakış açılarını ele almışlardır.

$\mathrm{Bu}$ makalede, Bayram vd. (2011) tarafindan, eğitime genel bakış odaklı yapılan çalışmaya ek olarak; öğrencilerin üniversite ve bölüm seçiminde etken olan faktörler, bölümleri hakkındaki düşünceleri ve genel/mesleki yetkinlikleri ile ilgili görüşleri ele alınarak, beklentilerin karşılanması ve yeterlilik bağlamında detaylandırma amaçlanmıştır.

Literatür bulguları Türkiye'de inşaat mühendisliği eğitimi ile ilgili çalışmaların ağırlıklı olarak tek bir bölüme odaklandığını, en kapsamlı çalışmanın ise Oğuz vd. (2009) tarafından yapıldığını göstermektedir. Fakat Oğuz vd. (2009) çalışmalarında yeni açılan ve kısıtlı imkanlara sahip bölümler ile uzun yıllardır eğitim veren ve imkanları nispeten geniş olan bölümlerin kıyaslanmasını amaçlamıştır. $\mathrm{Bu}$ çalışmanın odağında ise devlet üniversitelerinde uzun yıllardır verilen inşaat mühendisliği eğitiminin eksiklerinin belirlenmesi olmuştur. Bu nedenle çalışma kapsamında, uzun yıllardır eğitim veren ve öğrencilerin giriş puanları ve öğrenci sayıları birbirine yakın seviyede olan, şu anda Türkiye'de inşaat mühendisliği bölümleri arasında taban puanlara bakıldığında ilk 30 bölümden üçü örneklem olarak seçilmiştir.

\section{YÖNTEM}

Çalışmanın amacı, daha önce de belirtildiği üzere, inşaat mühendisliği bölümü öğrencilerinin tercih kararlarının sorgulanması ve mezun olma aşamasındaki öğrencilerin kendilerini mesleki ve genel yetkinlikler açısından değerlendirmeleridir. Bu kapsamda, "İnşaat mühendisliği bölümü öğrencilerinin eğitimlerinden beklentileri ne ölçüde gerçekleşmiştir?" problemine bilimsel ve sistematik bir yaklaşımla katkıda bulunmak esas alınmıştır. Bu durumda, araştırma yönteminin istatistiksel değerlendirmeye olanak sağlaması ve dolayısıyla olaylar arasındaki ilişkileri tanımlamak için sayısal veri kullanan nicel araştırma olmasına karar verilmiştir. Bahsi geçen probleme cevap aramak için, belirlenen amaçtan da sapmamak adına, öğrencilere standartlaştırılmış sorular yöneltilmesi ve geri bildirim alınması gerekmektedir. $\mathrm{Bu}$ nedenle, çalışmada kullanılan veriler anket yöntemi ile toplanmıştır. Anket araştırması, özel olarak belirlenmiş bir ana kütlenin içinden örneklem seçilerek gerçekleştirilen çalışma şeklinde ifade edilebilir ve belirli ölçüde güven verebilen bir örneklemden hareketle ana kütle hakkında genelleme yapılabilir. Bu noktada, güven verebilen bir örneklem seçimi sözkonusudur. Bu çalışmada; Çukurova Üniversitesi, Erciyes Üniversitesi ve Gazi Üniversitesi bünyesindeki inşaat mühendisliği bölümlerinde eğitim görmekte olan dördüncü sınıf öğrencilerine anket çalışması uygulanmış ve toplam 181 öğrenci ankete cevap vermiştir.

Örneklem seçiminde kontenjanlarının daha fazla olmasından dolayı devlet üniversiteleri esas alınmıştır. Devlet üniversiteleri arasında inşaat mühendisliği eğitimi veren bölüm sayısı günümüzde $67 \mathrm{iken}$, anket araştırmasının 2011 yılında yapıldığı gözönüne alındığında, bölüm sayısının 44 olduğu ifade edilebilir. Örneklemi geniş tutabilmek adına, bir başka ifadeyle daha fazla veri toplanabilmesi amaciyla, kontenjanı 100'ün üzerinde olan bölüm seçiminin uygun olacağ1 düşünülmüştür. Böylece, bölüm sayıs1 31 'e indirilmiştir. Bu noktada, uzun yıllardır eğitim veren bölüm seçimi ön plana çıkmaktadır. Bu şekilde, oluşumunu tamamlamamış bölümlerde görülebilecek olan sorunların önüne geçilmesi planlanmıştır. Bu açıdan değerlendirme yapıldığında, bölüm sayısı 20'ye düşmektedir. Bunlar arasında, benzer imkanlara sahip olan; 1960'lı yıllarda öğretime başlayan Gazi Üniversitesi'ne, 1979'da öğretime başlayan Çukurova Üniversitesi'ne ve 1991 'de öğrenime başlayan Erciyes Üniversitesi'ne bağlı inşaat mühendisliği bölümleri, örneklem için uygun görülmüş̧ür. 
Çalışmanın, mezun olma aşamasındaki öğrencilerin tercih kararlarının sorgulanması, öğrencilerin kendilerini mesleki ve genel yetkinlikler açısından değerlendirmeleri gibi birden fazla amaç taşıması nedeniyle, anket çalışmasının içeriğindeki sorular gruplandırılarak dört ana başlık halinde toplanmıştır. Birinci bölümde; üniversitenin yaşam alanına yakınlığının ve ekonomik durumun örneklem grubunun tercihinde etken olup olmadığının ortaya çıkarılabilmesi amacıyla, örneklem grubunun yaşadığı coğrafi bölge, ailenin sosyo-ekonomik durumu gibi genel bilgiler talep edilmiştir.

İkinci bölümde; bir önceki bölümdeki tercih etkenlerinin desteklenip desteklenmediğini, bunun yanısıra üniversite seçimi ile bölüm seçiminin paralellik gösterip göstermediğini belirlemek amacıyla, örneklem grubunun üniversite/bölüm seçiminde etken olan faktörler talep edilmiştir.

Üçüncü bölümde; bölümden ve sektörden duyulan memnuniyet düzeylerinin belirlenmesi amaciyla, örneklem grubunun bölümleri hakkındaki düşünceleri ile ilgili sorular yöneltilmiştir.

Anket çalışmasının dördüncü ve son bölümünde; örneklem grubuna ekip çalışması, liderlik, iletişim gibi beceri alanlarındaki genel yetkinlikleri, betonarme, malzeme, ulaştırma gibi temel alanlardaki mesleki yetkinlikleri, bunun yanısıra sektöre ait iş ilanlarında ön plana çıkan paket programların kullanımı ve yabancı dil seviyesi konularındaki yeterlilikleri ile ilgili sorular yöneltilmiştir.

Anket sorularının belirlenmesi aşamasında; İnşaat Mühendisleri Odası (IMO) tarafından yapılan ve sonuçları Oğuz vd. (2009) tarafından değerlendirilen öğrenci anketi incelenmiştir. İMO tarafından yapılan anket kapsamında; öğrencilere mesleği tercih nedenleri, eğitim hakkındaki düşünceleri, öğretim sürecinde sağlanan akademik ve fiziksel olanakların yeterliliği, öğretim elemanları ile ilişkileri, kültürel faaliyetleri gibi birçok konuda sorular yöneltilmiştir. Mevcut çalışmada, geniş bir dağılımdan ziyade öğrencilerin tercih kararları ile mesleki ve genel yetkinlikleri odaklı bir anket araştırması planlanarak, anket soruları özgün bir şekilde hazırlanmıştır.

Çalışmanın ikinci, üçüncü ve dördüncü bölümlerine ait sorularda, Rensis Likert tarafından geliştirilen Likert Ölçeği (1932) kullanılmıştır. Likert Ölçeği, bir şahsın tek bir objeye karş1 gösterdiği tutuma ilişkili olarak hazırlanmış cümle serisi içerir (Köklü, 1995). Likert Ölçeğinin en çok kullanılan formatında, ölçeğin uygulandığı cevaplayıcılar her bir cümleyi onaylama derecesini göstermek üzere yönlendirilir (Köklü, 1995). Kısaca, katılımcıya bir cümle sunulur ve onun iki, üç, dört, beş, altı ya da yedi seçeneği olan ölçekte, katılıp katılmadığı sorulur (Köklü, 1995). Bu çalışmada, nötr bir orta noktaya sahip olan ve en pratik ölçek yöntemi olarak gösterilen beşli Likert ölçeği kullanılmıştır. Örneklemden toplanan verilerin istatistiksel analizleri, "Microsoft Office Excel 2003 for Windows" ve "Statistical Package for Social Sciences (SPSS) 17.0 for Windows" yazılım programları aracılığı ile yapılmıştır. Anket çalışmasında yer alan grupların değerlendirilmesinde, her bir soruya verilen cevapların; ortalama ve standart sapma değerleri elde edilerek, bunlara bağlı yorumlar yapılmıştır. Bunun yanısıra, her bölümün toplam puanları dikkate alınmış ve her bir soruya verilen cevapların korelasyonu elde edilmiştir. Cevaplar değerlendirilirken Tablo 2, Tablo 3 ve Tablo 4'deki değerlendirme kriterlerinden yararlanılmıştır.

Tablo 2. İkinci Bölüm İçin Değerlendirme Kriterleri

\begin{tabular}{lll}
\hline Puan & Alt-Üst Sınır & Puana Karşılık Gelen Yorum \\
\hline 1.00 & $1.00-1.80$ & Hiç önemli değil \\
2.00 & $1.81-2.60$ & Önemli değil \\
3.00 & $2.61-3.40$ & Kararsızım \\
4.00 & $3.41-4.20$ & Önemli \\
5.00 & $4.21-5.00$ & Çok önemli \\
\hline
\end{tabular}

Tablo 3. Üçüncü Bölüm İçin Değerlendirme Kriterleri (Orhun, 2005)

\begin{tabular}{lll}
\hline Puan & Alt-Üst Sınır & Puana Karşılık Gelen Yorum \\
\hline 1.00 & $1.00-1.80$ & Kesinlikle katıllmıyorum \\
2.00 & $1.81-2.60$ & Katılııorum \\
3.00 & $2.61-3.40$ & Kararsızım \\
4.00 & $3.41-4.20$ & Katılıyorum \\
5.00 & $4.21-5.00$ & Tamamen katıllyorum \\
\hline
\end{tabular}


Tablo 4. Dördüncü Bölüm İçin Değerlendirme Kriterleri

\begin{tabular}{lll}
\hline Puan & Alt-Üst Sınır & Puana Karşılık Gelen Yorum \\
\hline 1.00 & $1.00-1.80$ & Oldukça yetersizim \\
2.00 & $1.81-2.60$ & Yetersizim \\
3.00 & $2.61-3.40$ & Kararsızım \\
4.00 & $3.41-4.20$ & Yeterliyim \\
5.00 & $4.21-5.00$ & Oldukça yeterliyim \\
\hline
\end{tabular}

\section{BULGULAR ve YORUMLAR}

Veri analizine öncelikle test yönteminde kullanılan ölçeğin güvenilirliğinin ölçülmesi ile başlanmıştır. Kullanılan ankete ait soruların homojen bir yapı gösteren bir bütünü ifade edip etmediğini ve kullanılan ifadelerin anlaşılırlığını araştırmak amacıyla, "İssel Tutarlılık Yöntemi" kapsamında hesaplanan "Cronbach Alpha Katsayısı" $(\alpha)$ dikkate alınmıştır. Her bir örneklem grubu için elde edilen $(\alpha)$ değerleri Tablo 5'de verilmektedir.

Tablo 5. Kullanılan Anketin Güvenilirlik Değerleri

\begin{tabular}{lc}
\hline Üniversite & $(\alpha)$ değeri \\
\hline Çukurova & .824 \\
Erciyes & .870 \\
Gazi & .927 \\
Genel & $\mathbf{. 8 7 9}$ \\
\hline
\end{tabular}

Cronbach Alpha Katsayısı değerlerinin 0.6'nın üzerinde olması, ölçeklerin "oldukça güvenilir" olduğunu göstermektedir (Kalayc1, 2008).

Tablo 6'da, Tablo 7'de ve Tablo 8'de, anket çalışmasının birinci bölümünde yer alan sorulardan elde edilen; örneklem grubunun üniversitelere göre dağılımı, ailelerinin yaşadıkları bölgeler ve ailelerinin sosyo-ekonomik durumları ile ilgili sorulara verilen cevapların dağılımları yer almaktadır.

Tablo 6. Örneklem Grubunun Üniversitelere Göre Dağılımı

\begin{tabular}{lcccccccc}
\hline & \multicolumn{2}{c}{ Cukurova } & \multicolumn{2}{c}{ Erciyes } & \multicolumn{2}{c}{ Gazi } & \multicolumn{2}{c}{ Genel } \\
\hline Program Türü & $\mathrm{n}$ & $\%$ & $\mathrm{n}$ & $\%$ & $\mathrm{n}$ & $\%$ & $\mathrm{n}$ & $\%$ \\
\hline Birinci Öğretim & 10 & 23 & 65 & 63 & 34 & 100 & 109 & 60 \\
İkinci Öğretim & 34 & 77 & 38 & 37 & 0 & 0 & 72 & 40 \\
Toplam & $\mathbf{4 4}$ & $\mathbf{2 4}$ & $\mathbf{1 0 3}$ & $\mathbf{5 7}$ & $\mathbf{3 4}$ & $\mathbf{1 9}$ & $\mathbf{1 8 1}$ & $\mathbf{1 0 0}$ \\
\hline
\end{tabular}

Tablo 6'da örneklem grubunun anket çalışması yapılan 3 üniversiteye göre dağılım oranları verilmiştir. Tablodaki verilerden en fazla katılımın Erciyes Üniversitesi'nden olduğu gözlemlenmektedir.

Tablo 7. Örneklem Grubunun Ailelerinin Yaşadıkları Bölgeler

\begin{tabular}{clll}
\hline Sıra No & \multicolumn{1}{c}{ Çukurova } & \multicolumn{1}{c}{ Erciyes } & \multicolumn{1}{c}{ Gazi } \\
\hline 1 & Akdeniz (23) & İç Anadolu (55) & İç Anadolu (24) \\
2 & Güneydoğu Anadolu (6) & Akdeniz (10) & Karadeniz (2) \\
3 & İç Anadolu (5) & Güneydoğu Anadolu (9) & Akdeniz (1) \\
\hline
\end{tabular}

Tablo 7'deki sonuçlar öğrencilerin yaşadıkları bölgelerdeki üniversiteleri tercih ettiklerini göstermektedir.

Tablo 8. Örneklem Grubunun Sosyo-Ekonomik Durumu

\begin{tabular}{ll}
\hline Üniversite & Ailenin Ayllk Gelir Düzeyi (Mod) \\
\hline Çukurova & 1001-1500 TL arası \\
Erciyes & 1501-2000 TL arası \\
Gazi & 3001 ve üstü \\
Genel & $1501-2000$ TL arası \\
\hline
\end{tabular}


Tablo 8'deki sonuçlar ise öğrencilerin ağırlıklı olarak orta gelir grubuna dâhil olduklarını göstermektedir.

Anket çalışmasının ikinci bölümünde, üniversite/bölüm seçiminde etken olan faktörler hakkında sorular sorulmuş ve sonuçlar, Tablo 9'da özetlenmiştir. Sonuçlar yorumlanırken, Tablo 2'de verilen kriterler baz alınmıştır.

Tablo 9. Öğrencilerin Üniversite ve Bölüm Seçiminde Etken Olan Faktörler

\begin{tabular}{|c|c|c|c|c|c|c|c|c|}
\hline & & Cevaplar & $\begin{array}{c}\text { Örneklem } \\
\text { Toplam Puanı }\end{array}$ & $\begin{array}{r}\text { Cevap } \\
\text { Korelasyonu } \\
\end{array}$ & $\begin{array}{c}\text { Örneklem } \\
\text { ortalamast }\end{array}$ & $\begin{array}{c}\text { En çok tercih edilen } \\
\text { seçenek }(\mathrm{Mod})\end{array}$ & $n$ & $\%$ \\
\hline \multirow{6}{*}{1} & \multirow{6}{*}{ 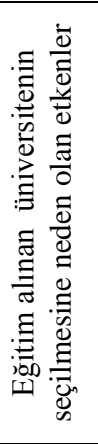 } & $\begin{array}{l}\text { Üniversitenin kalitesinin } \\
\text { tatmin edici olması }\end{array}$ & 669 & .97 & 3.82 & Çok Önemli (5) & 64 & 35 \\
\hline & & $\begin{array}{l}\text { Büyükşehirde eğitim görme } \\
\text { isteği }\end{array}$ & 629 & .96 & 3.67 & Önemli (4) & 57 & 31 \\
\hline & & $\begin{array}{l}\text { Üniversitenin, ailemin } \\
\text { yaşadığ } 1 \text { șehre yakın olması }\end{array}$ & 531 & .94 & 3.09 & Çok Önemli (5) & 48 & 27 \\
\hline & & Maddi s1kıntılar & 554 & .94 & 3.06 & Çok Önemli (5) & 45 & 25 \\
\hline & & $\begin{array}{l}\text { Üniversitenin burs, yurt, ev } \\
\text { vb. imkânlarının iyi olması }\end{array}$ & 531 & .96 & 2.97 & Hiç önemli değil (1) & 45 & 25 \\
\hline & & $\begin{array}{l}\text { Arkadaşlarımın/Yakınlarımın } \\
\text { aynı üniversitede eğitim } \\
\text { alıyor olması }\end{array}$ & 418 & .62 & 2.34 & li değil (1) & 71 & 39 \\
\hline \multirow{5}{*}{2} & \multirow{5}{*}{ 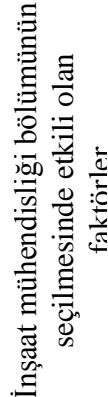 } & Mesleğe olan ilgi & 683 & .95 & 3.79 & Çok Önemli (5) & 66 & 36 \\
\hline & & $\begin{array}{l}\text { Mezuniyet sonrası iş bulma } \\
\text { olasılığımın yüksek olacağı } \\
\text { düşüncesi }\end{array}$ & 654 & .94 & 3.65 & Önemli (4) & 64 & 35 \\
\hline & & $\begin{array}{l}\text { Bölümün ÖSYM sınavı } \\
\text { sonucunda alınan puana en } \\
\text { yakın bölüm olması }\end{array}$ & 548 & .80 & 3.09 & Önemli (4) & 56 & 31 \\
\hline & & $\begin{array}{l}\text { Aile fertlerinin inşaat } \\
\text { sektöründe çalışıyor olması }\end{array}$ & 508 & .85 & 2.81 & Hiç önemli değil (1) & 63 & 35 \\
\hline & & $\begin{array}{l}\text { Aile fertlerinin baskıc1 } \\
\text { tutumu }\end{array}$ & 306 & -.65 & 1.80 & Hiç önemli değil (1) & 115 & 64 \\
\hline
\end{tabular}

Tablo 9'daki sonuçlar incelendiğinde ortalama ve mod değerlerinin genel olarak birbirine paralel olduğu görülmektedir. Bunun yanısıra, beşli Likert ölçeğinin her bir seçeneğine verilen cevaplar arasındaki korelasyonların da tatmin edici nitelikte olduğu ifade edilebilir. "İnşaat mühendisliği bölümünün seçilmesinde etkili olan faktörler" ana başlığı altında yer alan "Aile fertlerinin baskıcı tutumu" seçeneği için korelasyonun - .65 olması, ilgili soruya verilen cevaplar arasında ters yönlü bir doğrusal ilişki olduğunu göstermektedir.

"Eğitim alınan üniversitenin seçilmesine neden olan etkenler" ana başlığı altında yer alan faktörler arasında; "Üniversitenin kalitesinin tatmin edici olması" ve "Büyükşehirde eğitim görme isteği”nin öğrenciler açısından önem teşkil ettiği görülmektedir. "Üniversitenin, ailemin yaşadığ 1 şehre yakın olması", "Maddi sıkıntılar" ve "Üniversitenin burs, yurt, ev vb. imkânlarının iyi olması" seçeneklerinin ortalama değerleri "kararsızım" puanına karşılık gelmesine rağmen en çok tercih edilen seçenek incelendiğinde "Üniversitenin, ailemin yaşadığı şehre yakın olması" ve "Maddi sıkıntılar" seçeneklerinde öğrencilerin en çok tercih ettiği seçeneğin "çok önemli" olduğu gözlenmektedir. "Üniversitenin burs, yurt, ev vb. imkânlarının iyi olması" seçeneği için ise en çok tercih edilen seçenek "Hiç önemli değil" seçeneğidir. Bu üç madde de kararsızıma eşdeğer bir ortalamanın (2.60 ile 3.40 arası değerler) çıkmasının sebebi öğrencilerin kararsız olmalarından ziyade iki zıt kutupta yanıtlar vermeleridir. "Üniversitenin, ailemin yaşadığı şehre yakın olması" nın öğrencilerin çoğu için önemli olması Tablo 7'deki bulgularla paraleldir. "Arkadaşlarımın/yakınlarımın aynı üniversitede eğitim alıyor olması" faktörü ise, öğrenciler açısından önemsiz olarak nitelendirilmiştir.

"İnşaat mühendisliği bölümünün seçilmesinde etkili olan faktörler" ana başlığı altında yer alan hususlarda ise; "Mesleğe olan ilgi" nin en önemli etken olduğu gözlenmektedir. Bu durum, öğrencilerin bölüm tercihlerinde bilinçli olduklarını göstermektedir. "Mezuniyet sonrası iş bulma olasılığımın yüksek olacağı düşüncesi" ikinci sırada yer almaktadır. "Bölümün ÖSYM sınavı sonucunda alınan puana en yakın bölüm olması" seçeneğinin ortalama skoruna göre öğrencilerin bu konuda "kararsı" oldukları görülmekte fakat ankete verilen cevaplar tek tek incelendiğinde bu kararsızlığın kişi bazında olmadığı, yanıtların ‘önemli' ve 'hiç önemli değil' uç noktalarında toplandığı fakat bu konu ile ilgili 
öğrencilerin çoğunluklu olarak “önemli” seçeneğini işaretledikleri gözlenmiştir. "Aile fertlerinin baskıc1 tutumu" seçeneği ise öğrencilerin yine ortalama olarak "kararsız" olduklarını düşündürmekte fakat en çok tercih edilen seçenek incelendiğinde öğrencilerin "Hiç önemli değil" seçeneğinde yoğunlaştı̆̆ gözlenmiştir. $\mathrm{Bu}$ da, aile fertlerinin baskıcı tutumunun bölüm seçiminde etkisiz olduğunu göstermektedir.

Anket çalışmasının üçüncü bölümünde, öğrencilere bölümleri hakkındaki düşünceleri ile ilgili sorular yöneltilmiştir. Elde edilen genel sonuçlar, Tablo 10'da verilmektedir. Sonuçlar yorumlanırken, Tablo 3'den faydalanılmıştır.

Tablo 10. Öğrencilerin Okudukları Bölüm Hakkındaki Düşünceleri

\begin{tabular}{|c|c|c|c|c|c|c|}
\hline Cevaplar & $\begin{array}{c}\text { Örneklem } \\
\text { Toplam } \\
\text { Puanı }\end{array}$ & $\begin{array}{l}\text { Cevap } \\
\text { Korelasyonu }\end{array}$ & $\begin{array}{l}\text { Örneklem } \\
\text { ortalamast }\end{array}$ & $\begin{array}{l}\text { En çok tercih edilen } \\
\text { seçenek (Mod) }\end{array}$ & $n$ & $\%$ \\
\hline $\begin{array}{l}\text { Hayat boyu çalışmak istediğim ideal mesleğe } \\
\text { sahibim. }\end{array}$ & 673 & .98 & 3.69 & $\begin{array}{l}\text { Tamamen katıliyorum } \\
(5)\end{array}$ & 60 & 33 \\
\hline Bölümümden genel olarak memnunum. & 666 & .91 & 3.67 & Katıliyorum (4) & 71 & 39 \\
\hline Mümkün olsa farklı bir meslek seçerdim. & 416 & .61 & 2.40 & $\begin{array}{l}\text { Kesinlikle } \\
\text { kat1lmiyorum (1) }\end{array}$ & 81 & 45 \\
\hline $\begin{array}{l}\text { Mezun olduktan sonra inşaat sektöründe çalışmak } \\
\text { istemiyorum. }\end{array}$ & 365 & -.12 & 2.09 & $\begin{array}{l}\text { Kesinlikle } \\
\text { katılmiyorum (1) }\end{array}$ & 95 & 52 \\
\hline
\end{tabular}

Öğrencilerin, eğitim almakta oldukları bölüm ile ilgili genel düşünceleri konusunda, bölümlerinde isteyerek ve severek eğitim aldıkları görüşü ön plana çıkmaktadır. Öğrenciler, hayat boyu çalışmak istedikleri ideal mesleğe sahip olduklarını ve bölümlerinden genel olarak memnun olduklarını ifade etmektedirler. Bölümleri hakkındaki genel düşünceler konusunda öğrencilerin ortalama skorları ile mod değerleri birbirine paraleldir. Bunun yanısıra, beşli Likert ölçeğinin her bir seçeneğine verilen cevaplar arasındaki korelasyonların da tatmin edici nitelikte olduğu ifade edilebilir. "Mezun olduktan sonra inşaat sektöründe çalışmak istemiyorum" seçeneği için korelasyonun - .12 olması, ilgili soruya verilen cevaplar arasında ters yönlü bir doğrusal ilişki olduğunu göstermektedir ki ilgili soruya verilen cevaplar çoğunlukla olumsuz olmuştur.

Anket çalışmasının dördüncü ve son bölümünde, öğrencilere; genel yetkinlik, mesleki yetkinlik, paket program kullanımı ve yabancı dil seviyesi konularındaki yeterliliklerini belirlemek amacıyla yöneltilen sorulara cevap vermeleri istenmiştir. Elde edilen genel sonuçlar, Tablo 11'de verilmektedir. Sonuçlar yorumlanırken, Tablo 4'den faydalanılmıştır.

Tablo 11. Genel ve Mesleki Yetkinlikler

\begin{tabular}{|c|c|c|c|c|c|c|c|}
\hline & & Cevaplar & $\begin{array}{c}\text { Örneklem } \\
\text { ortalaması }\end{array}$ & Ss & $\begin{array}{c}\text { En çok tercih } \\
\text { edilen seçenek }(\mathrm{Mod})\end{array}$ & $n$ & $\%$ \\
\hline \multirow{7}{*}{1} & \multirow{7}{*}{ 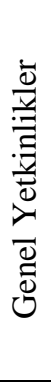 } & Başkalarıyla iyi ilişkiler kurabilme & 4.18 & .89 & Oldukça yeterliyim (5) & 78 & 43 \\
\hline & & $\begin{array}{l}\text { Sorunlu durumları iyi yönetebilme ve } \\
\text { sorun çözebilme }\end{array}$ & 4.17 & .82 & Yeterliyim (4) & 88 & 49 \\
\hline & & İşbirliği, ekip çalışması yapabilme & 4.16 & .90 & Oldukça yeterliyim (5) & 77 & 43 \\
\hline & & Pratik düşünme ve davranabilme & 4.12 & .97 & Yeterliyim (4) & 83 & 46 \\
\hline & & Liderlik yapabilme & 4.06 & .94 & Yeterliyim (4) & 76 & 42 \\
\hline & & Haklarını savunabilme & 4.05 & .96 & Yeterliyim (4) & 70 & 39 \\
\hline & & $\begin{array}{l}\text { Sözlü ve yazılı iletişimi etkili } \\
\text { kullanabilme }\end{array}$ & 3.93 & 1.01 & Yeterliyim (4) & 82 & 45 \\
\hline \multirow{11}{*}{2} & \multirow{11}{*}{ 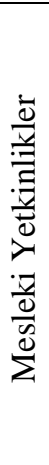 } & Betonarme Yapılar & 3.96 & .97 & Yeterliyim (4) & 79 & 44 \\
\hline & & Yapı İşletmesi-İnşaat Yönetimi & 3.58 & 1.09 & Yeterliyim (4) & 58 & 32 \\
\hline & & $\mathrm{Su}$ Yapıları & 3.56 & 1.09 & Yeterliyim (4) & 59 & 33 \\
\hline & & Teknik Çizim & 3.56 & 1.25 & Yeterliyim (4) & 55 & 30 \\
\hline & & Yapı Malzemeleri & 3.52 & 1.00 & Yeterliyim (4) & 65 & 36 \\
\hline & & Zemin Yapıları & 3.40 & 1.10 & Yeterliyim (4) & 60 & 33 \\
\hline & & Ulaştırma Yapıları & 3.34 & 1.13 & Kararsızım (3) & 61 & 34 \\
\hline & & Mekanik & 3.18 & 1.04 & Kararsızım (3) & 74 & 41 \\
\hline & & Çelik Yapılar & 3.01 & 1.21 & Kararsızım (3) & 53 & 29 \\
\hline & & Ahşap Yapılar & 2.69 & 1.19 & Kararsızım (3) & 51 & 28 \\
\hline & & Kıy1-Liman Yapıları & 2.36 & 1.19 & Oldukça yetersizim (1) & 78 & 43 \\
\hline
\end{tabular}




\begin{tabular}{|c|c|c|c|c|c|c|}
\hline & \multirow{6}{*}{ 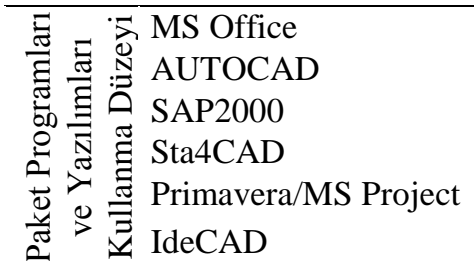 } & 3.95 & 1.21 & Oldukça yeterliyim (5) & 67 & 37 \\
\hline & & 3.91 & 1.00 & Yeterliyim (4) & 77 & 43 \\
\hline & & 3.25 & 1.25 & Kararsızım (3) & 50 & 28 \\
\hline 3 & & 2.42 & 1.41 & Oldukça yetersizim (1) & 64 & 35 \\
\hline & & 2.05 & 1.31 & Oldukça yetersizim (1) & 97 & 54 \\
\hline & & 1.99 & 1.24 & Oldukça yetersizim (1) & 88 & 49 \\
\hline \multirow{6}{*}{ 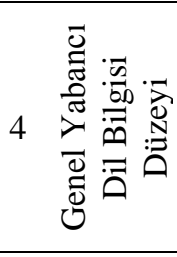 } & $\overline{0} \quad$ İngilizce & 3.62 & .96 & Yeterliyim (4) & 78 & 43 \\
\hline & $\overrightarrow{\tilde{E}} \vec{s} \ldots$ Almanca & 1.51 & .85 & Oldukça yetersizim (1) & 121 & 67 \\
\hline & बే పే స్ట Arapça & 1.38 & .83 & Oldukça yetersizim (1) & 137 & 76 \\
\hline & 釭 & 1.37 & .97 & Oldukça yetersizim (1) & 136 & 75 \\
\hline & Fransizca & 1.36 & .85 & Oldukça yetersizim (1) & 141 & 78 \\
\hline & İspanyolca & 1.26 & .68 & Oldukça yetersizim (1) & 146 & 81 \\
\hline
\end{tabular}

Genel yetkinlikleri konusunda öğrencilerin kendilerini ankette sıralanan alt başlıkların tümünde yeterli gördükleri ortaya çıkmakla birlikte, öğrenciler 'başkalarıyla iyi ilişkiler kurabilme' yetkinliğinde nispeten daha iyi olduklarını düşünmektedirler. Buna rağmen sözlü ve yazılı iletişimi etkili kullanabilme yetkinliğinin genel yetkinlikler arasında en düşük puanı almış olması, öğrencilerin resmi iletişim konusunda güven problemleri olduğunu göstermektedir. Genel yetkinlikler incelendiğinde öğrencilerin ortalama skorları ile mod değerlerinin birbirine paralel olduğu gözlenmektedir.

Mesleki yetkinlik konusunda, öğrenciler; betonarme yapılar, yapı işletmesi/inşaat yönetimi, su yapıları, teknik çizim ve yapı malzemeleri konularında yeterli olduklarını ifade etmişlerdir. Kıyı-liman yapıları alanında ise öğrencilerin yetersiz olduklarını düşündükleri ortaya çıkmaktadır. Ayrıca öğrenciler çelik yapılar konusunda, diğer konulara göre daha düşük yetkinliğe sahip olduklarını düşünmektedirler. "Zemin yapıları" konusunda ortalama skorlara göre "kararsı"” bir tutum sergiledikleri gözlenmektedir. Bu konuda en çok tercih edilen seçeneğin ise "yeterliyim" olduğu görülmüş, ortalamadaki kararsızlık, öğrenciler arasında uç cevaplar olmasından kaynaklıdır.

"Paket Programları ve Yazılımları Kullanma Düzeyi" konusunda ise, öğrencilerin özellikle MS Office ve AutoCAD yazılımlarının kullanımında yeterli düzeyde olduklarını düşündükleri görülmektedir. Yapı analizi paket programlarının kullanımı konusunda ise öğrencilerin yetersiz olduklarını düşündükleri sonucu ortaya çıkmaktadır. Bu konularda öğrencilerin ortalama skorları ile mod değerlerinin birbirine paralel olduğu gözlenmiştir.

"Genel Yabancı Dil Bilgisi Düzeyi” konusunda sorulan soruların cevapları değerlendirildiğinde ise, öğrenciler İngilizce seviyelerini yeterli gördüklerini, diğer yabancı dillerde ise oldukça yetersiz olduklarını ifade etmişlerdir. Öğrencilerin bu konudaki ortalama skorları ile mod değerleri de birbirine paraleldir.

Yukarıdaki bulgulara ek olarak öğrencilerin anketin dört ana bölümünde verdikleri cevapların birbirleri ile korelasyonları incelenmiş ve en yüksek korelasyon değeri (0.487 ile) "2. Bölüm: Üniversite/bölüm seçiminde etken olan faktörler" ve ; "3. Bölüm: Bölümden ve sektörden duyulan memnuniyet düzeyleri” arasında çıkmıştır. 0.487 korelasyon değeri beşeri kaynaklı araştırmalar için önemli bir ilişkiyi ifade eden bir değerdir. Bu sonuç da öğrencilerin bir bölümü bilinçli ve istekli olarak tercih ettikleri zaman aldıkları eğitimden memnuniyet derecelerinin yükseldiğini göstermektedir.

\section{TARTIŞMA ve SONUÇLAR}

2009-2013 yılları arasında geçen beş yıllık süreçte, ülkemizde bulunan inşaat mühendisliği bölümlerinin kontenjanlarının \%97 oranında artması, öğrencilerin mezuniyet sonrasında yoğun bir rekabetle karşı karşıya olduklarını göstermektedir. Bu rekabet ortamında öne geçebilmek için öğrencilerin kendi eksiklerini tarafsız olarak belirleyip tamamlamaya çalışmaları şarttır. Bu çalışma sonuçları da üç üniversitenin inşaat mühendisliği bölümü öğrencilerinin öğrenim yeterlilikleri ve mesleki yetkinlikleri konusunda kendilerini nerede gördüklerini özetlemektedir.

Örnekleme yapılan grup verileri esas alındığında, öğrencilerin üniversite tercihlerinde üniversitenin kalitesi ve büyük şehirde eğitim görme isteğinin ön plana çıtığ 1 , bölüm tercihlerinde ise mesleğe olan ilgilerinin en önemli etken olduğu ortaya çıkmıştır. Aile fertlerinin baskıcı tutumunun bölüm seçiminde etkisiz olduğu görülmektedir. Oğuz vd. (2009) tarafından yapılan çalışmada ise; tercih nedenleri adına öğrencilerin \%46'sının inşaat mühendisliği eğitimini yeteneklerine uygun bulduğu belirlenmiştir. Bu noktada, yeteneklerden ziyade üniversitenin kalitesinin tercih nedeni odağına dönüştüğü ifade edilebilir. 
Oğuz vd. (2009) tarafından yapılan çalışmada, öğrencilerin \%57'sinin inşaat mühendisliği bölümünü ilk üç tercihi arasına yazdığ 1 , bir başka ifadeyle bilinçli olarak inşaat mühendisliği mesleğini tercih etmiş oldukları belirlenmiş olup, mevcut çalışmadaki tespitle paralellik göstermektedir.

Oğuz vd. (2009) tarafından yapılan çalışmada, öğrencilerin \%86's1 eğitiminden memnun olduğunu ifade etmişken, bu çalışmada öğrencilerin bölümleri hakkındaki düşünceleri "Hayat boyu çalışmak istediğim ideal mesleğe sahibim" olarak ortaya çıkmış ve öğrencilerin yüksek memnuniyeti ile paralellik göstermiştir. Bu çalışmada da Oğuz vd (2009)'un bulgularına benzer şekilde, kendi isteği ile inşaat mühendisliği bölümüne gelmiş olan öğrencilerin bölümden ve seçtikleri meslekten memnuniyet seviyelerinin yüksek olduğu belirlenmiştir.

Genel yetkinlikleri konusunda öğrenciler 'başkalarıyla iyi ilişkiler kurabilme' yetkinliği konusunda başarılı olduklarını, 'sözlü ve yazılı iletişimi etkin kullanabilme' konusunda ise göreceli olarak daha az başarılı olduklarını düşünmektedirler. Oğuz vd. (2009) tarafından yapılan çalışmada da benzer sonuçlar elde edilmiştir. Bu durumda derslerde öğrencilere konuları ile ilgili ödevler verilip, hazırlanan ödevlerin sınıf önünde sunuş şeklinde anlatılmasının veya belirli konularda raporların hazırlatılmasının, öğrencilerin sözlü ve yazılı iletişim becerisini geliştireceği ve kendilerine olan güvenlerini pekiştireceği düşünülmektedir.

Mesleki yetkinlik konusunda, öğrenciler; betonarme yapılar, yapı işletmesi/inşaat yönetimi, su yapıları, teknik çizim ve yapı malzemeleri konularında yeterli olduklarını ifade etmiş̧lerdir. Kıyı-liman yapıları alanında ise öğrencilerin yetersiz olduklarını düşündükleri ortaya çıkmaktadır. Oğuz vd. (2009) tarafından yapılan çalışmada, öğrencilerin \%61'inin, kullanılan sistemin teorik bilgilerin öğrenilmesi için yetersiz olduğunu düşündüğü ortaya çıkmış ve nispeten daha karamsar bir tablo çizilmiştir.

Yapı analizi paket programlarının kullanımı konusunda, öğrencilerin yetersiz olduklarını düşündükleri, "Genel Yabanc1 Dil Bilgisi Düzeyi" konusunda ise İngilizce seviyelerini yeterli gördükleri belirlenmiştir. Diğer yabancı dillerde ise oldukça yetersiz oldukları görülmektedir. Paket program kullanımı konusunda bölümlerin sektör ile işbirliklerinin güçlendirilmesi, bölümlerde paket program ve alternatif yabancı dil kurslarının teşvik edilmesi, bu konulardaki yetersizliğin giderilmesi adına fayda sağlayacaktır.

$\mathrm{Bu}$ çalışmada, inşaat mühendisliği lisans eğitimi öğrenci bakış açısıyla yansıtılmaya çalışılmıştır. Bu çalışmanın bulgularının, daha detaylı çalışmalar adına yol gösterici nitelikte olacağı düşünülmektedir. Örneklem grubunun genişletilmesi, çalışmadan elde edilen bulguların genelleştirilmesi adına bir seçim olmakla birlikte, yapılacak olan anket araştırmalarının bütün üniversitelerin inşaat mühendisliği bölümleri için düşünülmesi, ortaya yanıltıcı sonuçlar çıkaracaktır. Yazarların bu konudaki beklentisi, devlet üniversitesi-vakıf üniversitesi ya da gelişimini tamamlamış bölüm-gelişmekte olan bölüm-yakın geçmişte eğitime başlayan bölüm vb. gruplandırmalar yapılarak ve bu gruplandırmalar dikkate alınarak bir yol izlenmesidir. Bunun yanısıra, inşaat mühendisliği eğitiminde rol oynayan bütün parametrelerin bir arada değerlendirilmesinin de, yapılacak olan çalışmaları odak noktasından uzaklaştıracağı düşünülmektedir. İleriki çalışmalarda; öğretim elemanları, yeni mezun inşaat mühendisleri, tecrübeli inşaat mühendisleri, işverenler gibi inşaat mühendisliği eğitiminin diğer paydaşlarının da konu ile ilgili bakış açılarının bilimsel yöntemler kullanılarak belirlenmesi ve sonuçların tüm paydaşları kapsayan bir bütün olarak değerlendirilmesi önerilmektedir.

\section{KAYNAKLAR}

Aytekin, M. (2006, Mayıs). Mühendislik eğitiminden beklenenler. Sözel bildiri, II. Ulusal Mühendislik Kongresi, Zonguldak.

Balas, L. (2009, Kasım). İnşaat mühendisliği eğitiminde sürdürülebilir gelişsim kavramı. Sözel bildiri, 1. İnşaat Mühendisliği Eğitimi Sempozyumu, Antalya.

Baran, T. ve Kahraman, S. (2004, Mayıs). Mühendislik eğitiminde probleme dayall ögrrenme modelleri. Sözel bildiri, I. Ulusal Mühendislik Kongresi, Izmir.

Bayram, S., Dirikgil, T., Tantekin Çelik, G., Bulut, N., Haktanır, T. ve Laptalı Oral, E. (2011, Eylül). Inş̧aat mühendisliği bölümü öğrencilerinin mevcut eğitim sistemine bakışı ve çözüm önerileri. Sözel bildiri, İnşaat Mühendisliği Eğitimi 2. Sempozyumu, Muğla.

Birinci, F. ve Koç, V. (2007, Ekim). Türkiye'de inşaat mühendisliği eğitiminin genel yapısı ve geliştirilmesi için yeni yaklaşımlar. Sözel bildiri, 4. İnşaat Yönetimi Kongresi, İstanbul.

Birinci, F. (2009, Kasım). Türkiye'de inşaat mühendisliği eğitiminin genel durumu, sorunları ve çözüm önerileri. Sözel bildiri, 1. İnşaat Mühendisliği Eğitimi Sempozyumu, Antalya. 
Christodoulou, S. (2004). Educating civil engineering professionals of tomorrow. Journal of Professional Issues in Engineering Education and Practice, 130(2), 90-94.

Çeçen, H., Sertyeşilışık, B., Aladağ, H., Yurdakul, E. ve Toptaş, F. (2009, Kasım). YTÜ inşaat mühendisiği yapı işletmesi yüksek lisans eğitiminin analizi. Sözel bildiri, 1. İnşaat Mühendisliği Eğitimi Sempozyumu, Antalya.

Çiçek, T., Seyrankaya, A., Cöcen, İ., Yenice, H., Malayoğlu, U., Onur, A.H., Kahraman, B. ve Şafak, S. (2004, Mayıs). Mühendislik aktif ĕgitiminde mesleksel becerilerin kazanılması. Sözel bildiri, I.Ulusal Mühendislik Kongresi, Izmir.

Engin, S., Atalay, H.M. ve Okay, F. (2009, Kasım). Inşaat mühendisliği bölümü öğrencilerinin performansını etkileyen faktörlerin değerlendirilmesi. Sözel bildiri, 1. İnşaat Mühendisliği Eğitimi Sempozyumu, Antalya.

Ertaş, H., Öztaş, A. ve Tekinkuş, M. (2009, Ekim). Staj ve bitirme projelerinin inşaat mühendisliğinin yapım yönetimi ĕ̆itimindeki katkısının incelenmesi: Gaziantep Üniversitesi mezunu inşaat mühendisleri üzerine bir uygulama. Sözel bildiri, 5. Ulusal Yapı İșletmesi/Yapım Yönetimi Kongresi, Eskișehir.

Gençoğlu, M.T. ve Cebeci, M. (1999, Ekim). Türkiye'de mühendislik ĕgitimi ve öneriler. Sözel bildiri, Mühendislik-Mimarlık Eğitimi Sempozyumu, İstanbul.

Gençoğlu, M.T. ve Gençoğlu, E. (2005a). Mühendislik eğitiminde yeni yaklaşımlar. Kaynak Elektrik, 195, 89-93.

Gençoğlu, M.T. ve Gençoğlu, E. (2005b, Kasım). Mühendislik lisans eğitimi ve başarl ölçütleri. Sözel bildiri, TMMOB Mühendislik Eğitimi Sempozyumu, Ankara.

Gross, K. and Godwin, P. (2005). Education's many stakeholders-educational administrators are increasingly recognizing what businesses have long understood: Customer satisfaction matters. University Business, $8(9)$.

Günay, D. ve Günay, A. (2011). 1933'den günümüze türk yükseköğretiminde niceliksel gelişmeler. Yükseköğretim ve Bilim Dergisi, 1(1), 1-22.

Kalaycı, Ş. (2008). SPSS Uygulamalı Çok Değişkenli İstatistik Teknikleri. Ankara: Asil Yayın.

Köklü, N. (1995). Tutumların ölçülmesi ve likerttipi ölçeklerde kullanılan seçenekler. Ankara Üniversitesi Ĕ̆gitim Bilimleri Fakültesi Dergisi, 28(2), 81-93.

Leung, M.I., Li, J., Fang, Z., Lu, X. ve Lu, M. (2006). Learning approaches of construction engineering students: A comparative study between Hong Kong and Mainland China. Journal for Education in the Built Environment, 1(1), 112-131.

Likert, R. (1932). A technique for the measurement of attitudes. Archives of Psychology, 22(140), 55.

Liu, X. ve Fang, D. (2002). Predicaments and expectations of civil engineering education in China. European Journal of Engineering Education, 27(2), 219-224.

Maric, I. (2013). Stakeholder analysis of higher education 1nstitutions. Interdisciplinary Description of Complex Systems, 11(2), 217-226.

Mıstıkoğlu, G. (2010, Eylül). Inşaat mühendisliği öğrencilerinin motivasyonlarını etkileyen faktörlerin değerlendirmesi üzerine örnek bir çalışma. Sözel bildiri, 1. Proje ve Yapım Yönetimi Kongresi, Ankara.

Mıstıkoğlu, G. (2012). İstanbul'daki inşaat mühendisliği öğrencilerinin motivasyonlarını etkileyen faktörlerin değerlendirmesi. e-Journal of New World Sciences Academy, 7(3), 632-641. http://www.newwsa.com/download/gecici_makale_dosyalari/NWSA-5930-2706-4.pdf adresinden elde edildi.

OECD, (2010). Education at a Glance 2009. OECD Indicators, Paris. http://dx.doi.org/10.1787/eag-2009-en adresinden elde edildi.

OECD, (2013). Education at a Glance 2013. OECD Indicators, OECD Publishing. http://dx.doi.org/10.1787/eag2013-en adresinden elde edildi.

Oğuz, C., Altın, S., Yaman, İ.Ö., Kırçıl, M.S., Bakır, A. ve Sönmez, G. (2009, Kasım). Inşaat mühendisliği eğitiminde Türkiye gerçeği. Sözel bildiri, 1. İnşaat Mühendisliği Eğitimi Sempozyumu, Antalya.

Orhun B.F. (2005). Resim-iş dersine ilişkin tutumların yorumlanması. Pamukkale Üniversitesi Eğitim Fakültesi Dergisi, 18, 19-29.

Papert, S. (1980, Ekim). Redefining childhood: The computer presence as an experiment in developmental psyschology. Sözel bildiri, IFIP Congress 80, 8th World Computer Congress, Tokio, Japan and Melbourne, Australia.

Riggs, L.S. (1988). Educating construction managers. Journal of Management in Engineering, ASCE, 114(2), 279285.

Sorguç, V.D. (2007, Ekim). Temel üretim ve maliyet işlevleri ışı̆̆ında inşaat endüstri, işletme mühendisliği ve stratejisinin eğitim sorunlart. Sözel bildiri, 4. İnşaat Yönetimi Kongresi, İstanbul.

Uğur, L.O. (2007). İnşaat mühendisliği eğitimindeki sorunlar, mesleki uygulama düzenlemeleri ve meslek kipi seçiminin değerlendirilmesi konularında bir alan çalışması. Inşaat Mühendisleri Odası Ankara Şubesi. http://www.imo.org.tr/resimler/ekutuphane/pdf/1576.pdf adresinden elde edildi. 
BAYRAM, ÇELIK, ORAL; Mühendislik öğrencilerinin öğrenim yeterlilikleri ve mesleki yetkinlikleri: inşaat mühendisliği ögrenci perspektifi

Warszawski, A. (1984) Construction management programme. Journal of Management in Engineering, ASCE, 110(3), 297-310.

Yenigün, K. ve Gürel, M.A. (2004, Mayıs). Türkiye’de inşaat mühendisliği eğitiminin değerlendirilmesi ve bazı öneriler. Sözel bildiri, I.Ulusal Mühendislik Kongresi, Izmir. 


\section{EKLER}

\section{EK 1}

Tablo 1.(a) İnşaat Mühendisliği Eğitimi Programları, 2009-2013 Öğrenci Kontenjanları, Öğretim Uyesi ve Öğretim Görevlisi Sayıları - Devlet Üniversiteleri

\begin{tabular}{|c|c|c|c|c|c|c|c|}
\hline Üniversite & $\begin{array}{c}\text { II. } \\
\text { Ogretım }\end{array}$ & (2009) & (2010) & (2011) & (2012) & (2013) & $\begin{array}{l}\text { Öğretim Üyesi } \\
\text { (Öğr.Görevlisi) }\end{array}$ \\
\hline Abdullah Gül & Yok & - & - & - & - & 21 & $2(0)$ \\
\hline Adıyaman & Yok & - & - & - & - & 41 & $4(0)$ \\
\hline ADU & Yok & - & - & - & - & 41 & $3(0)$ \\
\hline Akdeniz & Yok & 52 & 57 & 57 & 62 & 62 & $14(0)$ \\
\hline Aksaray & Var & 104 & 114 & 114 & 124 & 124 & $14(0)$ \\
\hline Anadolu & Yok & 52 & 57 & 57 & 62 & 62 & $13(0)$ \\
\hline Atatürk & Var & 164 & 176 & 176 & 186 & 186 & $23(2)$ \\
\hline Balıkesir & Var & 206 & 206 & 206 & 216 & 216 & $18(0)$ \\
\hline Bartın & Var & - & 94 & 94 & 104 & 104 & $5(0)$ \\
\hline Bayburt & Var & - & 114 & 114 & 124 & 124 & $3(2)$ \\
\hline Bilecik & Yok & - & - & 41 & 47 & 47 & $7(0)$ \\
\hline Bingöl & Yok & - & - & 52 & 57 & 57 & $3(0)$ \\
\hline Bitlis Eren & Var & - & - & 82 & 94 & 94 & $3(0)$ \\
\hline Boğaziçi & Yok & 57 & 57 & 57 & 62 & 62 & $20(0)$ \\
\hline Bozok & Var & 104 & 114 & 114 & 134 & 134 & $8(2)$ \\
\hline Bülent Ecevit & Var & 41 & 47 & 104 & 114 & 114 & $6(1)$ \\
\hline Celal Bayar & Var & 144 & 154 & 154 & 164 & 164 & $20(0)$ \\
\hline Cumhuriyet & Var & 82 & 114 & 114 & 124 & 124 & $4(1)$ \\
\hline Çukurova & Var & 144 & 154 & 154 & 164 & 164 & $18(0)$ \\
\hline Dicle & Var & 41 & 47 & 94 & 104 & 104 & $16(5)$ \\
\hline Dokuz Eylül & Var & 186 & 196 & 196 & 206 & 206 & $32(3)$ \\
\hline Dumlupinar & Var & 104 & 114 & 114 & 124 & 124 & $16(0)$ \\
\hline Düzce & Var & - & - & - & $94 * * *$ & $209 * * *$ & $5(0)$ \\
\hline Ege & Yok & 52 & 57 & 57 & 62 & 62 & $21(3)$ \\
\hline Erciyes & Var & 144 & 154 & 154 & 164 & 186 & $14(2)$ \\
\hline Erzincan & Var & - & - & - & 94 & 94 & $5(0)$ \\
\hline ETU & Var & - & - & - & - & 82 & $3(0)$ \\
\hline Firat & Var & 144 & 154 & 154 & $340 * * *$ & $342 * * *$ & $16(0)$ \\
\hline Gazi & Yok & 93 & 98 & $160 *$ & $185 * * *$ & $187 * * *$ & $27(5)$ \\
\hline Gaziantep & Var & 144 & 154 & 154 & 164 & 164 & $17(2)$ \\
\hline GOPU & Yok & - & - & - & 47 & 47 & $4(1)$ \\
\hline Gümüşhane & Var & 124 & 134 & 134 & 144 & 144 & $14(2)$ \\
\hline Harran & Var & 104 & 114 & 114 & 124 & 124 & $9(0)$ \\
\hline İnönü & Var & - & 36 & 72 & 82 & 104 & $9(0)$ \\
\hline İstanbul & Yok & 72 & 72 & 72 & 77 & 77 & $22(1)$ \\
\hline İTÜ & Yok & 271 & 271 & 271 & 282 & 282 & $93(7)$ \\
\hline İYTE & Yok & - & - & 41 & 47 & 47 & $12(0)$ \\
\hline KTÜ & Yok & 370 & 370 & $432 *$ & $514 * * *$ & $259 * * *$ & $33(2)$ \\
\hline Karabük & Var & - & - & - & 114 & 134 & $3(0)$ \\
\hline Kirıkkale & Var & 104 & 114 & 114 & 124 & 124 & $7(1)$ \\
\hline Kirklareli & Yok & - & - & - & - & 41 & $4(0)$ \\
\hline Kilis 7 Aralık & Var & - & - & - & 94 & 94 & $2(0)$ \\
\hline Kocaeli & Var & 144 & 154 & 154 & 164 & 164 & $13(0)$ \\
\hline Kocatepe & Yok & - & - & - & 47 & 47 & $13(0)$ \\
\hline KNEU & Yok & - & - & - & 47 & 47 & $5(0)$ \\
\hline Korkut Ata & Var & - & - & 62 & 82 & 82 & $4(0)$ \\
\hline MAEU & Yok & - & - & - & - & 41 & $7(0)$ \\
\hline Mersin & Yok & - & - & - & - & 41 & $3(0)$ \\
\hline MSKU & Yok & 41 & 47 & 47 & 52 & 52 & $10(0)$ \\
\hline MKU & Var & 164 & 176 & 176 & 186 & 186 & $17(0)$ \\
\hline NKU & Yok & 52 & 57 & 57 & 62 & 62 & $13(0)$ \\
\hline Niğde & Var & 104 & 114 & 114 & 134 & 134 & $12(0)$ \\
\hline OMU & Var & 104 & 114 & 114 & 124 & 124 & $10(0)$ \\
\hline ODTÜ & Yok & 233 & 239 & 240 & 268 & 268 & $56(0)$ \\
\hline Osmangazi & Var & 186 & 196 & 196 & 206 & 206 & $25(0)$ \\
\hline Pamukkale & Var & 164 & 176 & 176 & 186 & 186 & $26(1)$ \\
\hline RTEU & Yok & - & - & - & - & 41 & $4(0)$ \\
\hline Sakarya & Var & 186 & 248 & $248 *$ & $320 * * *$ & $322 * * *$ & $28(0)$ \\
\hline
\end{tabular}


BAYRAM, ÇELIK, ORAL; Mühendislik öğrencilerinin öğrenim yeterlilikleri ve mesleki yetkinlikleri: inşaat mühendisliği ögrenci perspektifi

\begin{tabular}{lrrrrrrr} 
Selçuk & Var & 164 & 176 & 176 & 186 & 186 & $24(5)$ \\
SDU & Var & 186 & 196 & 196 & 206 & $310^{* * *}$ & $27(0)$ \\
KSU & Var & 31 & 36 & 72 & 94 & 104 & $5(1)$ \\
Şırnak & Var & - & - & 72 & 104 & 114 & $5(0)$ \\
Tunceli & Var & - & 104 & 104 & 114 & 114 & $1(3)$ \\
Uludağ & Yok & - & - & 31 & 36 & 36 & $5(0)$ \\
Uşak & Yok & - & - & - & - & 31 & $5(0)$ \\
YTÜ & Yok & 268 & 268 & 268 & 278 & 180 & $57(3)$ \\
Yüzüncü Yı1 & Yok & - & 31 & 31 & 36 & 36 & $6(0)$ \\
\hline
\end{tabular}

Tablo 1.(b) İnşaat Mühendisliği Eğitimi Programları, 2009-2013 Öğrenci Kontenjanları ve Öğretim Uyesi ve Öğretim Görevlisi Sayıları - Vakıf Üniversiteleri

\begin{tabular}{|c|c|c|c|c|c|c|c|}
\hline Üniversite & $\begin{array}{c}\text { II. } \\
\text { Ogretım } \\
\end{array}$ & (2009) & (2010) & (2011) & (2012) & (2013) & $\begin{array}{l}\text { Öğretim Üyesi } \\
\text { (Öğr.Görevlisi) }\end{array}$ \\
\hline Arel & Yok & - & - & 60 & 60 & 60 & $3(1)$ \\
\hline Atılım & Yok & 60 & 60 & 70 & 60 & 70 & $10(0)$ \\
\hline Avrasya & Yok & - & - & 60 & 70 & 80 & $3(0)$ \\
\hline Aydın & Yok & - & - & 60 & 70 & 70 & $6(0)$ \\
\hline Beykent & Yok & 51 & 60 & 70 & 70 & 80 & $4(0)$ \\
\hline Bilgi & Yok & - & - & - & 50 & 60 & $2(0)$ \\
\hline Bursa Orhangazi & Yok & - & - & - & 40 & 48 & $3(0)$ \\
\hline Canik Başarı & Yok & - & - & - & 60 & 70 & $4(0)$ \\
\hline Çankaya & Yok & - & - & - & 50 & 55 & $6(0)$ \\
\hline Fatih & Yok & - & - & - & 96 & 100 & $8(0)$ \\
\hline FSMU & Yok & - & - & 50 & 50 & 50 & $12(0)$ \\
\hline HKU (Gazikent) & Yok & - & - & 100 & 100 & 54 & $4(1)$ \\
\hline Gediz & Yok & - & - & 60 & 70 & 80 & $6(1)$ \\
\hline Gelişim & Yok & - & - & - & 55 & 55 & $7(0)$ \\
\hline Işı1k & Yok & - & - & 85 & 85 & 140 & $5(0)$ \\
\hline İzmir Ekonomi & Yok & - & - & - & - & 50 & $4(0)$ \\
\hline Katip Çelebi & Yok & - & - & - & 36 & 36 & $5(1)$ \\
\hline Kemerburgaz & Yok & - & - & - & 56 & 60 & $3(0)$ \\
\hline Kültür & Yok & 90 & 90 & 95 & 155 & 160 & $11(2)$ \\
\hline KTO Karatay & Yok & - & - & - & - & 50 & $4(0)$ \\
\hline Maltepe & Yok & - & - & 40 & 110 & 104 & $4(0)$ \\
\hline Melikşah & Yok & - & - & - & - & 46 & $5(0)$ \\
\hline Nişantaşı & Yok & - & - & - & - & 60 & $3(0)$ \\
\hline NNYU & Yok & - & - & 40 & 55 & 55 & $3(0)$ \\
\hline Okan & Yok & - & 70 & 70 & 70 & 85 & $7(0)$ \\
\hline Özyeğin & Yok & - & - & - & 60 & 70 & $3(0)$ \\
\hline Toros & Yok & - & - & - & 50 & 50 & $4(0)$ \\
\hline Turgut Özal & Yok & - & - & - & - & 55 & $4(0)$ \\
\hline Uluslararası Antalya & Yok & - & - & - & 60 & 60 & $1(0)$ \\
\hline Yeditepe & Yok & 50 & 70 & 80 & 80 & 85 & $5(0)$ \\
\hline Zirve & Yok & - & 60 & 60 & 70 & 70 & $4(0)$ \\
\hline Doğu Akdeniz & Yok & 71 & 153 & 122 & 179 & 134 & $11(0)$ \\
\hline GAU & Yok & - & - & - & 80 & 75 & $2(0)$ \\
\hline Lefke Avrupa & Yok & 25 & 60 & 60 & 55 & 55 & $4(0)$ \\
\hline Uluslararas1 Kibris & Yok & 38 & 90 & 90 & 95 & 60 & $7(0)$ \\
\hline \multirow[t]{2}{*}{ Yakın Doğu } & Yok & 27 & 125 & 120 & 120 & 140 & $3(2)$ \\
\hline & LAM*** & 5.542 & 6.713 & 7.949 & 10.273 & 10.924 & $1058(63)$ \\
\hline
\end{tabular}

* Teknoloji fakültelerinde yer alan inşaat mühendisliği bölümlerinin kontenjanları dâhil edilmiştir.

** Mesleki ve teknik ortaöğretim kurumu mezunları (MTOK) kontenjanları dâhil edilmiştir.

*** Devlet ve Vakıf Üniversiteleri toplamı. 